\title{
LA REVOCACIÓN DE SENADORES DE DESIGNACIÓN AUTONÓMICA, (LA LEY VALENCIANA 10/2016 Y LA STC 123/2017)
}

\author{
VICENTE NAVARRO MARCHANTE
}


SUMARIO

1. INTRODUCCIÓN. 2. BREVE REFERENCIA A LAS NORMAS ESTATALES Y AUTONÓMICAS SOBRE DESIGNACIÓN DE SENADORES Y NORMAS SOBRE LA PÉRDIDA DE LA CONDICIÓN DE SENADOR. 3. LA LEY VALENCIANA 10/2016. 3.1 Antecedentes. 3.2. La regulación de la revocación en la Ley valenciana 10/2016. 3.3. Otras iniciativas autonómicas similares. 4. APROXIMACIÓN A LA NATURALEZA DEL MANDATO Y LA REVOCACIÓN EN LA DEMOCRACIA REPRESENTATIVA. 4.1. Aspectos generales. 4.2. Aspectos específicos en torno a los senadores de designación autonómica. 5. LA STC 123/2017. 6. CONCLUSIONES. 7. BIBLIOGRAFÍA. 


\title{
LA REVOCACIÓN DE SENADORES DE DESIGNACIÓN AUTONÓMICA ${ }^{1}$, (LA LEY VALENCIANA 10/2016 Y LA STC $123 / 2017^{2}$ )
}

\author{
VICENTE NAVARRO MARCHANTE ${ }^{3}$ \\ Universidad de La Laguna
}

\section{INTRODUCCIÓN}

A finales del año 2016, el Parlamento autonómico de la Comunidad Valenciana aprobó la Ley 10/2016 que introducía, de forma novedosa en nuestro derecho autonómico, la posibilidad de revocar a los senadores de designación autonómica. En este trabajo se analizará esa Ley y su encaje constitucional.

La Constitución Española de 1978 establece en su Título III un legislativo bicameral, compuesto por el Congreso de los Diputados y por el Senado. Al Senado se le atribuye ser la cámara de representación territorial (art.69.1), aunque su diseño queda lejos de proporcionarle esa función de forma adecuada. El Senado ha sido objeto

${ }^{1}$ El presente trabajo forma parte del Proyecto de I+D del Ministerio de Economía y Competitividad DER 2014-57128-P «Transparencia institucional, participación ciudadana y lucha contra la corrupción». Una versión inicial fue presentada como comunicación en el Congreso de la Asociación de Constitucionalistas de España celebrado en marzo de 2017 en León. Para su elaboración se ha contado con financiación de la Beca del Ministerio de Educación José de Castillejo para la realización de una estancia de investigación en la Universidad de Pisa bajo la dirección del prof. Roberto Romboli. Se deja constancia del agradecimiento al Dr. José Ignacio Navarro Méndez, Letrado del Parlamento de Canarias, por su ayuda y sugerencias.

${ }^{2}$ Nota del autor: después de la aceptación del presente trabajo por la RDP y ya en la fase de maquetación del correspondiente número de la Revista, se ha publicado la STC 123/2017, de 2 de noviembre (BOE n. ${ }^{\circ} 278$ de 16 de noviembre de 2017) que resuelve el recurso de inconstitucionalidad planteado contra la Ley Valenciana 10/2016. Por esta razón, agradezco a la RDP el esfuerzo por concederme unos pocos días para poder incluir los aspectos esenciales de la declaración de inconstitucionalidad de la norma autonómica.

${ }^{3}$ Profesor de Derecho Constitucional. Departamento de Derecho Constitucional, Ciencia Política y Filosofía del Derecho. Camino La Hornera, 37. Facultad de Derecho. Universidad de La Laguna. Apartado 456. 38200. San Cristóbal de La Laguna. Santa Cruz de Tenerife. 
de numerosos estudios por parte de nuestra doctrina ${ }^{4}$, incluida la forma de elección de sus miembros. Como es sabido, la Constitución (art.69 CE, complementada por los arts. 161 y 165 LOREG) prevé dos sistemas de elección de senadores ${ }^{5}$, un primer sistema es el de elección popular directa por los ciudadanos, que elegirán a cuatro senadores en cada una de las 47 provincias peninsulares, tres en las islas de Mallorca, Tenerife y Gran Canaria, dos en cada una de las ciudades de Ceuta y Melilla y uno en cada una de las islas de La Palma, La Gomera, El Hierro, Fuerteventura, Lanzarote, Menorca e Ibiza-Formentera (el total de senadores elegidos por este método es de 208). El otro sistema de elección es el de designación por parte de las asambleas legislativas de las Comunidades Autónomas, a razón de un senador por cada Comunidad Autónoma y otro más por cada millón de habitantes que tenga esa Comunidad; en la actualidad, teniendo en cuenta que por este sistema el número de senadores no es cerrado, estos senadores de designación suponen en torno a un quinto del total. El art.69.5 CE prevé que esta designación corresponde a las Asambleas legislativas autonómicas «de acuerdo con lo que establezcan los Estatutos, que asegurarán en todo caso, la adecuada representación proporcional».

De esta manera, se observa que la opción del constituyente no se equipara a la que se establece en el modelo de Bundesrat o Consejo Federal alemán ${ }^{6}$, en el que sus miembros (en número variable de entre un mínimo de tres y un máximo de seis, en función de la población del Land) representan a los Gobiernos de los Länder y todos ellos votan en el mismo sentido según las instrucciones de sus respectivos gobiernos en lo que podemos llamar «mandato imperativo» ${ }^{7}$.

${ }^{4}$ Como muestra de los numerosos estudios doctrinales en torno al Senado, véanse estos dos trabajos de recopilación de referencias doctrinales: VV.AA. (1999). «Bibliografía sobre el Senado español y otras cámaras altas de representación territorial». Revista de las Cortes Generales, 47, $305-$ 380; y Núñez Martínez, M. y Reviriego Picón, F. (2006). «Repertorio bibliográfico sobre el Senado». TRC, 17, 449-474.

5 El acuerdo del constituyente es fruto del consenso político, como otros muchos en el texto de 1978, y con la percepción de cierta provisionalidad hasta ver cómo iría evolucionando el nuevo Estado de las Autonomías que se perfilaba en el texto constitucional; para un análisis de la tramitación parlamentaria véase García-Escudero Márquez, P. (1995). Los senadores designados por las Comunidades Autónomas. Madrid, Cortes Generales y CEC, pp. 71 y ss.

${ }^{6}$ Pese a que parte de nuestra doctrina sostuvo que, en términos teóricos, era la mejor opción para el sistema para evitar la división del voto de la representación del territorio autónomo y favorecer la coordinación entre la Administración estatal descentralizada y la política territorial autonómica (véase Trujillo Fernández, G. (1978). «La regionalización del Estado». Estudios sobre el proyecto de la Constitución. Madrid, CEC, p.520; Punset, R. (1983). «La designación de senadores por las Comunidades Autónomas». REDC, 8, p.167).

7 Para un análisis detallado del sistema de votación en el Bundesrat, en castellano, véase MEYER H. (2006). «Los votos en el Bundesrat». TRC, 17, 65-105. Torres del Moral (Torres Del Moral, A. (2003-2004). «Veinticinco años de Senado». RDP, 58-59, p. 494), aunque valora positivamente el modelo alemán, cree que su adopción en España puede ser conflictiva porque a la opinión pública, si ya le cuesta aceptar la disciplina de voto de los representantes respecto a sus partidos, también le puede costar aceptar el mandato imperativo de los Gobiernos autonómicos. 
El diseño de Senado español también queda lejos de otros modelos de segundas cámaras territoriales federales o regionales que ofrece el derecho comparado ${ }^{8}$. Con el modelo belga comparte que hay senadores elegidos de diferentes formas, unos por elección popular directa y otros por designación de los Consejos de las Comunidades (aunque en éste también hay senadores elegidos por cooptación y miembros natos de la familia real). Con el modelo austríaco comparte que en éste los senadores son (todos) elegidos por las asambleas legislativas de los estados miembros (hay nueve y eligen entre tres y doce representantes en función de la población de cada uno), siguiendo un reparto que garantice que la segunda fuerza del parlamento del Land obtiene, al menos, un puesto. Estos representantes pueden ser personas ajenas al Landtag, no son portadores de voto uniforme y, una vez en el Senado federal, se agrupan por ideología, no por territorios. Por su parte, en el Senado de los EEUU, formado actualmente por dos senadores en representación de cada uno de los 50 Estados miembros y elegidos por sufragio popular directo, hay que recordar que antes de la aprobación de la XVII Enmienda (1913) los senadores eran elegidos por los legislativos de los Estados, sin mandato imperativo y no sometidos a recall.

\section{BREVE REFERENCIA A LAS NORMAS ESTATALES Y AUTONÓMICAS SOBRE DESIGNACIÓN DE SENADORES Y SOBRE LA PÉRDIDA DE LA CONDICIÓN DE SENADOR}

Los candidatos a senadores de designación por sus respectivas CC.AA. están sometidos a una serie de requisitos de inelegibilidad e incompatibilidad que se establecen, en primer lugar, en el art.70.1 CE, que también son de aplicación a los miembros del Congreso de los Diputados. En segundo lugar, también hay que tener presente las previsiones del Reglamento del Senado y de la Ley Orgánica del Régimen Electoral General.

Junto a estas normas generales, cada Comunidad Autónoma regula en su Estatuto, Ley autonómica y/o Reglamento de la Cámara el procedimiento de elección de estos senadores de designación autonómica. La STC 89/1984 se pronunció expresamente admitiendo que la remisión del art.69.5 CE a lo que estableciesen los EE.AA. respecto a la designación de los senadores debía entenderse como una reserva relativa, aceptando que el Estatuto determine las directrices de la materia pero pueda remitirse a otras fuentes.

Existe cierto debate doctrinal ${ }^{9}$ en torno a la conveniencia de que la regulación de este procedimiento sea mediante una Ley específica ${ }^{10}$ o en el Reglamento parlamen-

\footnotetext{
${ }^{8}$ Puede verse una exposición de varios de esos sistemas en VV.AA. (1996) El Senado, Cámara de representación territorial. III Jornadas de la AELPA. Madrid, Tecnos, en concreto de: EE.UU., Alemania, Bélgica, Italia y Austria.

9 Véase en García-Escudero, P. (1995). Los senadores designados por las Comunidades Autónomas. Madrid, Cortes Generales y CEC, p.119 y ss.

${ }_{10}$ Es el caso, por orden de antigüedad de la ley vigente, de: País Vasco, Cantabria, Murcia, Asturias, Castilla La Mancha, Castilla León, La Rioja, Aragón Andalucía, Cataluña y Valencia.
} 
tario $^{11}$, la primera opción permite abordar aspectos sustantivos de los senadores de designación que van más allá del procedimiento de elección por parte de la asamblea legislativa, mientras que la segunda opción, la del Reglamento parlamentario, tendría la ventaja de recogerse en una norma que tiene la garantía formal añadida de requerir mayoría absoluta para su aprobación.

Algunas CCAA exigen o admiten que la elección recaiga en miembros de su Parlamento, en algunos casos para simultanear ambos cargos y en otros es previa renuncia al cargo de diputado autonómico. Otras CCAA excluyen esta exigencia y permiten que la designación de senador recaiga en personas ajenas al Parlamento autonómico. En algunos casos se especifica que el candidato debe ser residente en esa comunidad autónoma ${ }^{12}$.

La STC 40/1981, en relación con la Ley vasca de designación de senadores autonómicos, ya se pronunció sobre la constitucionalidad de la fijación de condiciones de elegibilidad añadidas a las generales de los Senadores en la normativa nacional, y declaró que la especificidad de esta forma de designación «nace de que, por corresponderles estos Senadores a las Comunidades Autónomas en cuanto tales, se confiere a los Estatutos un margen para precisar alguna condición directamente conectada con el carácter propio de dicha designación, dentro del mínimo fijado por el art.70.1 de la Constitución» y añade que «en todo caso, la inadmisibilidad de tales limitaciones vendría dada (...), por el hecho de que fuesen discriminatorias» y concluye que «la exclusión razonada de un candidato "por no reunir los criterios que señalen las leyes» no puede reputarse, en si misma, lesiva del derecho del derecho fundamental comprendido en el art.23.2 de la Constitución». Por tanto, el TC acepta la inclusión de nuevos requisitos de elegibilidad siempre que se respete el derecho de igualdad y cumpla con los parámetros de razonabilidad.

Sin ánimo de un análisis exhaustivo de los diecisiete procedimientos de designación, veremos algunos que muestran las diferencias existentes. En Andalucía, tras las elecciones autonómicas, es la Mesa, de acuerdo con la Junta de Portavoces, la que «fijará el número de Senadores que corresponda proporcionalmente a cada Grupo Parlamentario» (art.108 RPAnd); se confecciona una papeleta con todos los candidatos propuestos, equivalentes al número total de senadores a designar por la asamblea legislativa, $\mathrm{y}$ «El diputado o diputada marcará con una cruz el recuadro correspondiente a los candidatos a quienes otorga su voto hasta un máximo coincidente con el de propuestas presentadas»

\footnotetext{
11 Es el caso de: Extremadura, Madrid, Canarias, Galicia, Islas Baleares y Navarra.

12 A juicio de Pauner Chulvi («Los requisitos de elegibilidad de los senadores de designación autonómica». Revista de las Cortes Generales, 41, 1997, p.140) no hay problema en aceptar que las normas autonómicas que introducen nuevas causas de inelegibilidad para estos senadores, lo que podría interpretarse como una restricción al art.23.2 CE sobre el derecho de acceso a cargos y funciones públicas, sean válidas en tanto que las CCAA tienen título competencial para tal regulación y el TC, desde sus primeras sentencias, ha defendido una interpretación restrictiva sobre las materias reservadas a Ley Orgánica, queriendo evitar que toda norma que incida sobre los derechos fundamentales tenga que revestir tal carácter (véanse las SsTC 37/1981 y 6/1982 que precisan que la reserva de ley orgánica del art.81 se refiere al desarrollo directo del derecho fundamental, excluyendo las normas que tengan conexión o incidencia tangencial).
} 
(art.5 de la Resolución del Parlamento de Andalucía de 9 de abril de 2008, sobre la designación por el Parlamento de los Senadores en representación de la Comunidad Autónoma de Andalucía); por tanto, es evidente que todos los candidatos saldrán elegidos, pues basta un solo voto para ello y es presumible que los miembros de cada grupo parlamentario proponente votarán, al menos, por su candidato.

En Baleares se sigue el mismo procedimiento para determinar el número de senadores que corresponde proponer a los Grupos Parlamentarios, y se prevé que el Presidente de la Cámara «convocará el Pleno del Parlamento para que las ratifique» (art.189.4 RPBal). De la misma forma en Galicia (art.165 RPGal).

En Extremadura hay idéntico procedimiento para determinar el número de senadores que corresponde proponer a los Grupos Parlamentarios, con ellos se elabora una lista que será sometida a «votación de conjunto en el Pleno»(art.246.5 RPExt). De la misma forma en Madrid (art.225.5 RPMad).

En el caso de la Comunidad Valenciana, la Ley 9/2010, de 7 de julio, de designación de Senadores y Senadoras en representación de la Comunitat Valenciana, prevé en su art.2 que la Mesa, de acuerdo con la Junta de Sindics, «distribuirá proporcionalmente entre los Grupos Parlamentarios de la Cámara el número de Senadores o Senadoras (...); para ello aplicará la regla D’Hondt al número de Diputados y Diputadas que posea cada grupo", en caso de empate se favorece al grupo que hubiese obtenido más votos populares. No es necesario que los candidatos sean diputados autonómicos y se prevé un extenso catálogo de incompatibilidades (art.4). La Ley prevé que en la votación en el Pleno de la Cámara «cada Diputado o Diputada podrá votar como máximo una candidatura de las presentadas por los grupos parlamentarios y resultarán designados todos los que hayan resultado votados». Por tanto, al no prever un número mínimo de votos, basta un solo voto de alguno de los diputados autonómicos para resultar designado como senador.

En todo caso, sí resulta ineludible el mandato constitucional que obliga a que se asegure la adecuada representación proporcional de las fuerzas políticas presentes en la asamblea legislativa autonómica ${ }^{13}$. Por esta razón, en la práctica, independientemente de la norma autonómica que se utilice para su regulación y del procedimiento específico que se diseñe ${ }^{14}$, la elección de las personas que resultarán elegidas senadores de designación recae sobre los grupos parlamentarios, aunque el acuerdo formal corresponda al Pleno autonómico que, en general, no tendrá margen real de

13 En todo caso, las SsTC 40/1981, 75/1985 y 4/1992 aceptan que la representación proporcional debe entenderse de forma flexible, pues no es posible un sistema de proporcionalidad pura sin desviaciones por lo que la proporcionalidad debe entenderse más bien como una orientación o criterio tendencial, aunque las eventuales desviaciones podrán ser revisables en amparo si están desprovistas de criterio objetivo y razonable que permita justificarlas.

${ }^{14}$ Véase un análisis de los diversos sistemas en GARCía-Escudero (1995) op.cit. p.187 y ss. que clasifica los sistemas en: a) Único senador a elegir (en CCAA de menos de un millón de habitantes); b) De voto limitado; c) De asignación por la Mesa sin regulación del método de distribución; d) De asignación por la Mesa aplicando el sistema d’Hondt. 
decisión. Además, también prevén esas mismas normas que, en caso de producirse una baja de alguno de los senadores designados, únicamente podrá proponer a un sustituto el mismo grupo parlamentario que propuso al senador a sustituir.

Respecto a la pérdida de la condición de senador, el Reglamento del Senado prevé en su art.18 cuáles son esas causas, todas ellas de carácter objetivo no sujetas a margen de apreciación ${ }^{15}$. El apartado f) está reservado a los senadores de designación autonómica y hace referencia a que éstos pueden finalizar su mandato, según lo que prevea la norma autonómica, coincidiendo con la renovación de la asamblea legislativa designante tras las elecciones autonómicas o no. Hay Comunidades Autónomas que formulan las designaciones coincidiendo con las legislaturas de las Cortes Generales y otras que lo hacen al renovar el Parlamento Autonómico.

Las normas autonómicas suelen reproducir las causas de cese o pérdida de la condición de senador que contempla el Reglamento del Senado y, en su caso, añaden otras causas propias referidas a incompatibilidades o pérdida de condiciones específicas contempladas en la norma propia; no obstante, hay que destacar que siempre se trata de causas objetivas sin margen de apreciación. Se trataría, por ejemplo (art.14 de la Ley valenciana 9/2010), de la pérdida de la condición de miembro del Parlamento designante en aquellos casos en los que así se prevé en la norma autonómica; o la pérdida de la condición política de pertenencia a determinada CCAA (se trata de requisitos añadidos que han sido admitidos por la STC 40/1981).

En síntesis ${ }^{16}$, en nuestro ordenamiento jurídico las causas de pérdida del mandato parlamentario previstas en los Reglamentos de las Cámaras se establecen, de forma restrictiva, asociándose a causas naturales (fallecimiento o incapacitación decretada por el juez), a decisiones judiciales (anulación de la elección o de la proclamación, sentencias de inhabilitación absoluta o especial), a la extinción del mandato (por expiración del plazo o por disolución anticipada), o a la renuncia voluntaria del parlamentario (a lo que pueden asociarse las incompatibilidades sobrevenidas, con la consiguiente facultad para optar).

\section{LA LEY VALENCIANA 10/2016}

\subsection{Antecedentes}

El 16 de febrero de 2016, una diputada del Grupo Parlamentario Podemos-Podem en Les Corts de Valencia solicitó a la Mesa del Parlamento autonómico que pidiese un informe a los servicios jurídicos de la cámara «sobre la posibilidad de revocar de su cargo a Rita Barberá Nolla como Senadora por designación autonómica, considerando

15 Para un análisis doctrinal de las mismas véase GARCíA-Escudero (1995), op.cit. p.344 y ss.

16 Véase Ortega Santiago, C. (2005) El mandato representativo de los diputados y senadores, Congreso de los Diputados, Madrid, p.170. 
las circunstancias actuales» ${ }^{17}$. La Mesa aceptó que se elevara ese breve informe sobre la petición formulada ${ }^{18}$. El informe jurídico concluía que un procedimiento de revocación de un senador o senadora designado por la cámara «en ausencia de una previsión legal expresa que lo autorice, comportaría una lesión del derecho fundamental reconocido en el art.23.2 CE» y en consecuencia sería nulo de pleno derecho. No obstante, unos días antes de la emisión de ese informe, el Grupo Parlamentario Podemos-Podem presentó una proposición de ley para la modificación de la ley autonómica 9/2010, de 7 de julio, de Designación de Senadores o Senadoras en Representación de la Comunitat Valenciana, que, entre otros cambios que prevén una mayor exigencia de control de estos senadores por parte de la cámara legislativa autonómica designante, introducía la importante novedad de la posible revocación del senador designado.

La proposición de ley tuvo informe favorable del Gobierno valenciano (al tratarse de una iniciativa legislativa parlamentaria y no gubernamental, no era preceptivo el informe del Consejo Jurídico Consultivo), aunque advirtió de la conveniencia de prever causas tasadas que justificasen la revocación y de establecer la necesidad de alcanzar mayorías cualificadas que asegurasen un alto consenso y que se aportasen suficientes garantías al procedimiento.

En fase de enmiendas, los Grupos Parlamentarios Podemos-Podem, Ciudadanos, Compromís y Socialista consensuaron un texto que acabó convirtiéndose en la Ley 10/2016, de 28 de octubre ${ }^{19}$, de modificación de la Ley 9/2010 para la designación de senadores de representación autonómica.

Frente a esta Ley valenciana, los senadores populares presentaron un recurso de inconstitucionalidad que fue admitido a trámite ${ }^{20}$.

${ }^{17}$ La senadora Rita Barberá, ex alcaldesa de la ciudad de Valencia y ex presidenta del Partido Popular de Valencia, fue designada senadora en representación de la CA de Valencia el 2 de julio de 2015, a propuesta del Grupo Parlamentario Popular. Con posterioridad a esa fecha, la senadora se vio envuelta en una serie de procesos judiciales relacionados con financiación ilegal del Partido Popular en Valencia y en otros casos de corrupción política de los que venían afectado al PP valenciano desde años atrás. A petición de los dirigentes nacionales del PP, y en medio de un ambiente de fuerte crítica política y presión mediática, la senadora no dimitió de su cargo pero en septiembre de 2016 solicitó la baja del Grupo Popular en el Senado y pasó al Grupo Mixto. Finalmente la senadora falleció pocas semanas después, el 23 de noviembre de 2016.

${ }_{18}$ El escrito fue presentado por la diputada Fabiola Meco Tebar (RE n. $\left.{ }^{\circ} 14.024\right)$ y originó el Informe de 1 de marzo de 2016 suscrito por el letrado de Les Corts Juan A. Martínez Corral.

19 La Ley fue votada en el pleno del 19 de octubre de 2016 y obtuvo 62 votos favorables (Podemos-Podem, Compromís, Ciudadanos y Socialista) y 27 en contra, de los diputados del Partido Popular. Hay que señalar que el portavoz del Grupo Socialista, en el debate en pleno previo a la votación, manifestó sus reticencias jurídicas y políticas a la ley (D. S. n. ${ }^{\circ} 63$ de 2016).

${ }^{20}$ Véase Acuerdo del Pleno del TC de 28 de febrero de 2017 (N. ${ }^{\circ}$ asunto 649/2017). El recurso se dirige contra los apartados uno, tres, cuatro, cinco y siete del artículo único y contra la Disposición transitoria única. En síntesis, el recurso (páginas 16 a 21) tiene por objeto: a) la introducción en la ley autonómica de la posibilidad de revocación del senador de designación autonómica por pérdida de confianza como una forma de exigencia de responsabilidad política; b) la obligatoriedad de la comparecencia del senador ante la cámara como una forma de rendición de cuentas y control del ejercicio del cargo público; c) la pretendida aplicación retroactiva de la norma a los senadores anteriormente designados. 
Por su parte, el Gobierno de España, a través de la Dirección General de Coordinación de Competencias con las Comunidades Autónomas y las Entidades Locales, ante las dudas de constitucionalidad de la ley valenciana ${ }^{21}$, inició el trámite previsto en el art.33.2 de la LOTC con un acuerdo de inicio de negociaciones con la CA de Valencia que fue infructuoso, por lo que finalmente también presentó recurso el 28 de julio de 2017 en términos similares al planteado por el grupo de senadores.

Finalmente, en un tiempo bastante reducido para los tiempos habituales de los pronunciamientos del TC, a dos de noviembre de 2017 se produjo la STC 123/2017 que analizaremos después.

\subsection{La regulación de la revocación en la Ley valenciana 10/2016}

En primer lugar, resulta sorprendente que, pese a ser la introducción de la posibilidad de revocación el contenido fundamental de la reforma, en el Preámbulo de la Ley no se hace ninguna mención a este procedimiento, que se incluye como un novedoso art. 14 bis y obliga a modificaciones parciales de otros artículos de la Ley de 2010 (arts. 1, 13 y 14), y se limita a hacer referencia al resto del contenido de la ley de reforma: la supresión de la comparecencia previa de los candidatos a ser designados senadores (se suprime el art.9); una nueva regulación de las comparecencias de los senadores designados ante la cámara designante para rendir cuentas de la actividad desarrollada en la Cámara Alta (nueva redacción al art.16); y a otros aspectos formales sobre la forma de cubrir vacantes (nueva redacción del art.15). Como dato añadido a este hecho incomprensible $e^{22}$, se puede observar como el debate parlamentario previo a la votación final de la Ley gira, casi exclusivamente, en torno a las diferentes posiciones políticas de los grupos por la introducción del mecanismo revocatorio ${ }^{23}$.

El art.14 bis introducido por la Ley de 2016 regula el procedimiento para poder llevar a cabo la revocación. En él se prevé quién tiene iniciativa para activar el procedimiento, las causas de revocación, la tramitación y los requisitos para aprobarla.

\section{a) Iniciativa}

La propuesta para iniciar un proceso revocatorio corresponde a «un mínimo de dos grupos parlamentarios que representen, como mínimo, de $(\mathrm{sic})^{24}$ una décima parte de los miembros de la cámara» (art.14.bis.1).

${ }^{21}$ Las dudas de constitucionalidad se centran en el art.14.bis, que introduce el procedimiento revocatorio, y en el art.16, que establece un sistema de comparecencias de los senadores ante las Cortes valencianas y establece su obligatoriedad.

22 Desconocemos si se trata de un ejemplo de deficiente técnica legislativa (Directrices de técnica normativa aprobadas por Acuerdo del Consejo de Ministros de 22 de julio de 2005, publicadas en el $B O E$ n..$^{\circ} 180$ de 29 de julio de 2005 , sobre el contenido recomendado a la exposición de motivos véase la directriz 12) o si responde a alguna otra razón de estrategia política.

23 Véase el Diario de Sesiones del 19 de octubre, páginas 3042 a 3053.

${ }^{24}$ La errata, y no es la única, figura tanto en la versión publicada en el $B O E$ n. ${ }^{\circ} 283$ de 23 de noviembre de 2016 como en la versión en castellano publicada en el BOGV n. ${ }^{\circ} 7.911$ de 7 de noviembre de 2016. 
Por tanto, se abre la posibilidad a que tan sólo dos grupos parlamentarios, eventualmente opositores del grupo político al que pertenece el senador a revocar, además con un escaso porcentaje de representación, pueden provocar el inicio del procedimiento contra el senador designado (indirectamente también contra el Grupo parlamentario que lo propuso), como luego se verá al atender a la sustanciación en público del procedimiento. Todo ello, además, quizá aún a sabiendas de que su iniciativa de revocación es muy minoritaria dentro de la Cámara y tiene nulas posibilidades de ser aprobada. Estos bajos requisitos para la iniciativa de revocación contrastan con los sustancialmente más exigentes que se establecen para que la revocación prospere y que veremos más adelante.

\section{b) Causas}

El escrito dirigido a la Mesa del parlamento autonómico debe exponer las causas que según los proponentes justifican la pérdida de confianza (art.14.bis.2) y que podrían ser dos:

- Incumplimiento por parte del senador o senadora de las obligaciones establecidas en la actual ley.

- Actuaciones que comporten el desprestigio de las instituciones.

Respecto a la primera de las causas, el incumplimiento de las obligaciones establecidas en la actual ley, se trata de las nuevas obligaciones de comparecencia de los senadores ante la cámara designante a los efectos de rendición de cuentas de su actividad en la Cámara Alta, establecidos en el art.16 de la Ley. La nueva disposición, además de establecer la obligación de que los senadores designados deban comparecer ante la Cámara designante para informar «sobre temas relacionados con la actividad parlamentaria» a petición de los grupos parlamentarios, prevé que haya una comparecencia de los senadores ante la Comisión de Coordinación, Organización y Régimen de las Instituciones «para rendir cuentas de su trabajo en el Senado», al menos una vez al año ${ }^{25}$. Dado el carácter obligatorio de las comparecencias mencionadas (art.16.3), se puede deducir que la negativa del senador a acudir implicaría incumplimiento de sus obligaciones y, por tanto, constituiría causa de revocación.

${ }^{25}$ La redacción de este precepto responde a ciertas recomendaciones de la doctrina que entiende que el designado es, en cierta medida, deudor de una Cámara a la que representa, lo que «debiera suponer la obligación de mantener un control difuso en el tiempo sobre el designado y no, como sucede en la actualidad, que tras la elección, tras la designación, las relaciones entre los elegidos, los designados, y el Parlamento se diluyan hasta desaparecer y por ello proponía establecer métodos de control del senador autonómico, defendía articular un mecanismo de rendición de cuentas anual y de participación regular en los trabajos del Parlamento autonómico designante» (Visiedo MAzón F. J. (2002). «La designación de senadores en la Comunidad Valenciana, artículo 11.j) del Estatuto de Autonomía: las limitadas posibilidades de mejora a través de la reforma de la ley de designación y del reglamento de las Cortes Valencianas». Corts, 12, p.288). 
Hay que tener en cuenta que el art.16 de la anterior Ley de 2010, al igual que otras normas equivalentes en otras Comunidades Autónomas españolas, establecía que tanto las comisiones como los grupos parlamentarios puedan solicitar la comparecencia de los senadores designados por la Cámara autonómica para que informen sobre temas relacionados con su actividad parlamentaria que sea de interés para la Comunidad Autónoma, así como que el senador, a iniciativa propia, solicite comparecer ante las comisiones de la Cámara. Especial mención merece el Estatuto de Autonomía de Baleares de 2007 cuyo artículo 50.1 prevé que «El senador o los senadores designados por el Parlamento de las Illes Balears comparecerán ante la comisión parlamentaria pertinente a iniciativa propia o a requerimiento de un grupo parlamentario o de una quinta parte de los diputados para informar de su actividad en el Senado en los términos que establezca el Reglamento del Parlamento de las Illes Balears». No obstante, la Ley valenciana de 2010, como tampoco otras normas equivalentes de otras CCAA, no preveía que el senador pudiera negarse a comparecer ni, en consecuencia, las posibles sanciones.

Por otra parte, hay que señalar que no existe ningún precedente jurisprudencial sobre este asunto. Únicamente podemos hacer alusión a un informe de los propios servicios jurídicos de Les Corts ${ }^{26}$, en el que se resuelve una consulta realizada por el portavoz del Grupo parlamentario de Compromís y de la Mesa de la Comisión de Coordinación, Organización y Régimen de las Instituciones de la Generalitat como consecuencia de la negativa a comparecer por parte de la senadora Rita Barberá. Su conclusión es que si bien existe una obligación del senador de designación de comparecer ante la Cámara, esta «no se encuentra respaldada por una acción jurídica que, ante una negativa explícita como la analizada, permita hacer efectiva la comparecencia».

En esta primera causa de posible revocación, aunque aparentemente puede considerarse como una causa objetiva (constatar si el senador comparece o no ante la asamblea designante según establece el art.16 de la Ley), no hay que descartar problemas de interpretación y apreciación subjetivas, por ejemplo por considerar que no comparece cuando se le cita pero sin negarse a ello en un futuro y argumenta su postura, o que comparece pero no responde a todas las preguntas por considerar que algunas de ellas superan el vínculo entre senador designado y Cámara designante, o no lo hace en forma adecuada según los diputados autonómicos, etc.

Por otra parte, tampoco hay que descartar que la negativa a comparecer responda a una estrategia política premeditada del partido al que pertenece el senador. Pensemos, por ejemplo, que se trata de un partido cuya estrategia pasa por mostrar su desacuerdo con el sistema político negándose a participar en las instituciones, aunque sí concurre a los procesos electorales y luego sus cargos electos se mantienen al margen. En España hemos tenido casos de este tipo con partidos del entorno de Batasuna

${ }^{26}$ De la letrada de la Comisión de Coordinación, Organización y Régimen de las Instituciones de la Generalitat, Catalina Escuin Palop, de 8 de marzo de 2016. 
o, más recientemente, del independentismo catalán, e hipotéticamente podríamos especular con otras opciones que pudieran plantear estrategias similares: anarquistas, antisistema, etc. También pudiera ser el caso de la opción del movimiento «Escaños en Blanco» que abogan por no tomar posesión de los escaños que pudieran obtener en las urnas ${ }^{27}$ y que bien pudiera modificarse para que sí tomasen posesión de los escaños (incluida la posibilidad de que, en tanto eventual constitución de Grupo Parlamentario autonómico, pudieran decidir la designación de un senador autonómico) pero luego se mantuviesen al margen de toda actividad. Debemos tener en cuenta que nuestro ordenamiento jurídico no ha asumido de forma clara las tesis de lo que conocemos como «Democracia militante» (por ejemplo, véase la reforma de 1994 del art.50.1 de la LOREG que elimina la previsión de las campañas institucionales para incentivar la participación en las elecciones), por lo que en nuestra democracia se considera tan legítimo participar en los procesos como abstenerse.

Sin embargo, vemos, según el art.99.1 RCD, que el diputado, por acuerdo de la Mesa, podrá ser sancionado «Cuando de forma reiterada o notoria dejare de asistir voluntariamente a las sesiones del Pleno o de las Comisiones», pudiendo llegar, por acuerdo del Pleno, a una suspensión temporal de la condición de Diputado cuando haya reiteración en la conducta $(\operatorname{art} .101 .1 \mathrm{RCD})^{28}$. Aunque no se observa un precepto similar en el caso del Senado (el art.20.1 RS sólo establece que los «senadores tendrán el derecho y el deber de asistir a las sesiones plenarias y a las de las Comisiones de que formen parte»), es razonable suponer que pudiese ser incluido.

Lo que sí supondría un salto cualitativo sería que ese régimen sancionador disciplinario del Reglamento del Senado, ante posibles acciones reprobables (pero no delictivas), incluyese como causa de suspensión temporal de la condición de parlamentario el que el senador de designación autonómica incumpliese sus obligaciones de asistencia a las comparecencias en la Cámara designante; ciertamente, parece inviable aplicar un régimen sancionador interno, propio de la autonomía parlamentaria, a conductas que se desarrollarían fuera del ámbito de la Cámara que impone la sanción.

Por otra parte, lo que propone la Ley valenciana 10/2016 es que sea la cámara autonómica designante la que actúe por razones de naturaleza disciplinaria contra el senador designado, que formalmente es miembro de otra Cámara, el Senado (por mucho que en el origen de su designación haya estado presente la cámara autonómica y que el senador pueda mantener ciertos vínculos con ésta); esto también podría suponer una clara lesión de la autonomía parlamentaria del Senado y de sus miembros (arts.66.3 y 72.1 CE). Además, con el añadido de que la «sanción» sería sustancialmente más grave que en otros procedimientos sancionadores, que se inclinan por

27 Véase el manifiesto básico de esta opción en http://escanos.org/sobre-escanos-en-blanco/manifiesto/

${ }_{28}$ También hay que recordar los Autos del TC 127/1988 y 334/1993 sobre la reiterada ausencia de los diputados de Herri Batasuna a los Parlamentos Navarro y Vasco, respectivamente, y que dio por válida la suspensión de todos los derechos, incluidos los económicos. 
suspensiones temporales en los casos más graves, en tanto que la Ley valenciana habla de pérdida definitiva de la condición de senador.

En la línea de someter al senador designado a un sistema de control y de obligación de rendición de cuentas ante la cámara designante, una alternativa a la revocación podría ser someter al senador designado a un proceso de «reprobación», sin eficacia jurídica, a modo de escenificar públicamente una forma de censura por parte del órgano designante que pudiese suponer la obligación moral de dimisión del senador ante la pérdida de confianza ya materializada con el voto de reprobación. La STC 180/1991, al amparo de lo previsto en el art.111.2 CE, ha señalado que aunque estas mociones carecen de efectos vinculantes, son manifestación de la función de control y dirección de la Cámara y «revisten una indudable auctoritas». Esta misma vía se ha utilizado para reprobar la actuación de la Presidencia del Congreso de los Diputados cuando se discrepaba de su actuación ${ }^{29}$. Así mismo, y al amparo de lo dispuesto en el art.5.2 de la LO 3/1981, del Defensor del Pueblo, fue presentada una propuesta de reprobación y cese del Defensor del Pueblo en la VIII Legislatura, aunque rechazada por la Comisión Mixta de Relaciones con dicha Institución ${ }^{30}$.

Ciertamente, el Código penal (art.502) tipifica la negativa a comparecer ante las Comisiones de Investigación parlamentarias ${ }^{31}$, pero ampliar este artículo para considerar delito también la negativa del senador autonómico ante una Comisión de fiscalización política del parlamento de la Comunidad Autónoma designante (que pudiese suponer como eventual sanción la inhabilitación y, por tanto, la pérdida del escaño según lo previsto en el Reglamento del Senado) parece un salto cualitativo, por el sujeto y por el objeto, difícil de defender.

Respecto a la segunda de las causas, «actuaciones que comporten el desprestigio de las instituciones», hay que comenzar aludiendo a su alto grado de indefinición, y también podría recordarse la idea del concepto jurídico indeterminado. Es evidente que concluir que se está ante actuaciones que causen «desprestigio» requiere un previo juicio de valor, por definición subjetivo, que apela a juicios éticos, morales o políticos, y es imaginable que no siempre será sencillo que diversas fuerzas políticas

29 Boletín Oficial de las Cortes Generales, Congreso de los Diputados, Serie D, n. ${ }^{\circ} 647$ de 29 de diciembre de 2003 y Boletín Oficial de las Cortes Generales, Congreso de los Diputados, Serie D, n. ${ }^{\circ} 389$ de 19 de mayo de 2006.

${ }^{30}$ Diario de Sesiones, Cortes Generales, n. ${ }^{\circ} 84$, de 14 de febrero de 2007.

31 El art.502.1 CP prevé un delito de desobediencia grave para «Los que, habiendo sido requeridos en forma legal y bajo apercibimiento, dejaran de comparecer ante una Comisión de Investigación de las Cortes Generales o de una Asamblea Legislativa de Comunidad Autónoma, serán castigados como reos del delito de desobediencia. Si el reo fuera autoridad o funcionario público, se le impondrá además la pena de suspensión de empleo o cargo público por tiempo de seis meses a dos años». Para un análisis de este precepto véase Sessano Goenaga J. C. (2003). «El delito de incomparecencia ante comisiones parlamentarias de investigación como delito de «infracción de deber»; el sujeto activo de la conducta delictiva: el autor típico como obligado especial con un rol institucional». Anales de Derecho, 21. Universidad de Murcia, pp.283-298. 
de distinto signo coincidan al valorar motivaciones políticas legítimas frente a otras indignas o que desprestigien a las instituciones, dejar esa valoración a un órgano esencialmente político, que funciona con criterios políticos, es cuestionable.

No puede equipararse, evidentemente, con las causas de cese del cargo de senador designado que se establecían en el art.14 de la Ley valenciana de 2010, asimilables a otras normas autonómicas equivalentes, o las que prevé el art.18 del Reglamento del Senado, que señalaban circunstancias objetivas. No parece, pues, que se satisfagan las exigencias de tipicidad y de proporcionalidad que son propias de este ámbito y no se permite una mínima objetivación del proceso de enjuiciamiento previo a la sanción.

Por tanto, con esta segunda causa, la norma valenciana deja abierta de forma clara la posibilidad de plantear una revocación por razones políticas. Aquí también parece prudente plantearse si exigir ciertos comportamientos expresos a los representantes o impedir otros que no son constitutivos de delito, para mantener el mandato, implica demandar del representante una adhesión ideológica a ciertos principios, algo que no se prevé en nuestro sistema jurídico constitucional (Ortega, 2005, p.185).

\section{c) Procedimiento}

El procedimiento para tramitar la solicitud de revocación se regula en los apartados 3 y siguientes del art.14.bis.

\section{Admisión a trámite.}

En primer lugar, la solicitud debe ser admitida a trámite por la Mesa, en cuyo caso se llevará al orden del día del primer pleno ordinario que se ordene (art.14. bis.3). Se presupone que la Mesa debe examinar que la solicitud cumple con los requisitos y aquí puede comenzar a ser conflictiva la valoración de la concurrencia de la causa en el caso concreto que se haya planteado, especialmente si es por la segunda causa de revocación: que se trate de «actuaciones que comporten el desprestigio de las instituciones». A nuestro juicio, a los efectos de que la Mesa no se extralimite de sus funciones y asuma competencias que serían propias del Pleno, únicamente podría negarse si, al margen de los requisitos formales, la solicitud de revocación careciese de una mínima argumentación de la causa o fuese manifiestamente improcedente ${ }^{32}$.

32 Existe numerosa jurisprudencia constitucional respecto a las competencias de las Mesas en la admisión a trámite de todo tipo de iniciativas. La STC 212/2016, que cita la jurisprudencia anterior sobre el tema, resuelve un recurso de amparo de una diputada autonómica de Valencia a la que se inadmite una proposición no de ley y la resolución del Pleno (art.10.1.n) LOTC), declaró que se vulnera el art.23 CE ya que la Mesa acordó la inadmisión a trámite porque la decisión «carece de motivación suficiente conforme a las exigencias de nuestra doctrina» (FJ 6. ${ }^{\circ}$. 
En el caso de que la solicitud invoque la primera de las causas, el incumplimiento de las obligaciones del senador que marca la ley valenciana y que se concreta en las obligaciones de comparecencia, se sobreentiende que la Mesa debe comprobar que, efectivamente, se está ante una negativa a comparecer por parte del senador, por tanto debe constatar que haya sido debidamente citado, que se niegue a comparecer o a rendir cuentas y que no haya razones de fuerza mayor que lo justifiquen.

2. Comparecencia previa en Comisión del senador.

Antes de la celebración del pleno, el senador estará obligado a comparecer, en sesión pública, ante la comisión que la Mesa determine (art.14.bis 4). Se trata de un trámite que busca permitir que el senador afectado pueda defenderse y manifestar lo que le convenga y, teniendo en cuenta el principio general de publicidad de las actuaciones parlamentarias, es lógico que sea en público. Más aún teniendo en cuenta que la invocación del «desprestigio» presupone que ha trascendido a la opinión pública acciones contrarias a la dignidad del cargo por parte del senador y que hay un desmerecimiento en la consideración ajena.

Del tenor literal de la norma se deduce que la Mesa puede optar por remitir el asunto a una Comisión ya establecida con anterioridad y que, quizá, se venga ocupando de asuntos relacionados con el estatuto de los parlamentarios o temas disciplinarios, o bien crear una Comisión ad boc. No se especifica la forma en que esta comparecencia deba llevarse a cabo, tampoco opta la ley por remisión a otro tipo de procedimiento que pudiera utilizarse por analogía. En todo caso, se entiende que se debe garantizar un elemental derecho de oposición del senador, dentro de un procedimiento contradictorio frente a los solicitantes de la revocación, todo ello para evitar una situación de indefensión. Tampoco se prevé la forma de concluir esa comparecencia ni si la Comisión debe elevar algún tipo de informe, conclusiones o propuesta.

La norma sí prevé que en caso de inasistencia injustificada del senador, el trámite se da por cumplido y continua el procedimiento (art.14.bis 5). Esto último se trata de una previsión lógica y razonable, más teniendo en cuenta que una de las causas para invocar la revocación puede ser, precisamente, haberse negado antes a comparecer ante la Cámara para la rendición de cuentas.

\section{Debate y votación en Pleno.}

Tras el trámite de la comparecencia en Comisión, el asunto debe pasar al Pleno, los grupos promotores deberán defender la propuesta y habrá un debate con intervención del resto de grupos. Aquí sí se prevé en la Ley (art.14.bis 6) que las intervenciones de los grupos en el debate se realicen conforme al procedimiento utilizado para las proposiciones no de ley. 
No está prevista la participación en el Pleno del senador afectado en tanto que no es miembro de la Cámara autonómica, en la Comunidad Autónoma de Valencia no es posible simultanear el cargo de diputado autonómico y senador. Por esta razón, tampoco es necesario prever la posible obligación de abstención del diputado-senador de designación en este debate o en su votación. Ciertamente, la adopción de leyes de revocación similares a ésta de Valencia en Comunidades Autónomas en las que se puede simultanear ambos cargos plantearía numerosos conflictos añadidos con los que no parece oportuno especular en este trabajo.

Por tanto, la Ley considera que el derecho de defensa del senador afectado queda respetado al permitírsele hacer alegaciones en la comparecencia previa en Comisión, entendiendo que, al ser pública, ha podido ser seguida por todos los diputados autonómicos que forman el Pleno que va decidir y que éstos son conocedores de los argumentos y posición del senador afectado.

Finalizado el debate, se realizará una votación pública por llamamiento que requerirá una mayoría «de dos tercios de los miembros de la cámara y que no se produzca ningún voto negativo entre los diputados o diputadas que sean miembros de (sic) grupo parlamentario proponente del senador o senadora» (art.14.bis 7).

Respecto a este último requisito, al margen de que requerir la unanimidad dentro del grupo parlamentario que propuso al senador hace en la práctica que su aplicación sea casi imposible, se puede especular con que se podrían producir ciertas vicisitudes dentro del grupo parlamentario proponente entre el momento de la propuesta originaria del senador y la fecha en la que se pudiese votar sobre su revocación, por ejemplo por disolución del grupo al quedar por debajo del número mínimo de miembros previsto en el Reglamento (por las razones que sean: escisiones, bajas voluntarias, expulsiones, etc. $\left.{ }^{33}\right)$ que podría complicar la determinación exacta de quiénes son los diputados autonómicos que deben pronunciarse con unanimidad a favor de la revocación.

\section{d) Efectos}

En caso de prosperar la revocación, se informará a la Presidencia del Senado. La vacante producida será cubierta en la forma general prevista en el art.15 de la Ley para las vacantes producidas por cualquier otro tipo de circunstancias, esto es, sin que por ello se altere la representación proporcional (art.14.bis.8). Da por hecho la Ley que la Presidencia del Senado, a la vista del escrito proveniente de la Mesa del Parlamento autonómico valenciano, considerará que hay causa sobrevenida de extinción del mandato del senador designado y deberá ser sustituido por el suplen-

33 Entre ellas, habría que prestar también atención a los efectos que podría tener sobre el Grupo Parlamentario que propuso la designación la eventual aplicación de la LO 6/2002 y una posible disolución del partido político. 
te o, en su defecto, por el nuevo senador que designe el parlamento autonómico. A nuestro juicio, como se adelantaba anteriormente, esta posibilidad podría afectar a la inviolabilidad de las Cortes Generales establecida en el art.66.3 y al principio de la autonomía parlamentaria reconocido en el art.72.1 CE.

Se entiende que el senador revocado disconforme con la decisión del Parlamento valenciano, que debemos entender que se trata de un interna corporis acta dado que el procedimiento tanto de designación como de revocación queda fuera de control jurisdiccional, podría interponer un recurso de amparo ante el TC $^{34}$ (art.41.2 LOTC) alegando, muy probablemente, vulneración del art.23.2 CE. Por otra parte, en el caso de que no se hubiese presentado recurso de inconstitucionalidad contra la Ley valenciana 10/2016, sería una hipótesis plausible especular con que la Sala del TC a la que corresponda resolver un eventual recurso de amparo de un senador revocado llegue a la conclusión de que el origen de la posible lesión del derecho fundamental se encontraba en una norma de rango legal de dudosa constitucionalidad, por lo que debería plantear la autocuestión de inconstitucionalidad y elevar el asunto al Pleno del Tribunal, art.55.2 LOTC.

En caso de no prosperar la solicitud de revocación, los grupos proponentes (art.14.bis.9) no podrán presentar otra propuesta de revocación en el mismo periodo de sesiones. No especifica el precepto que deba tratarse de una segunda solicitud de revocación al mismo senador o senadora, por lo que debe entenderse que la posibilidad de volver a presentar una solicitud de revocación es general y se trata de una suspensión provisional que afectaría a todos los senadores de designación autonómica.

Finalmente, la Disposición transitoria única prevé que la nueva normativa tiene efecto retroactivo para los senadores designados conforme al procedimiento anterior, a excepción de las disposiciones relativas al procedimiento de nombramiento. Por tanto, la cámara autonómica se aseguraba la posibilidad de poder revocar a los senadores designados tras la constitución de la asamblea autonómica en 2015. Esta previsión, quizá, también podría plantear problemas respecto al principio de la irretroactividad $^{35}$ de las normas desfavorables o restrictivas de derechos fundamentales (art.9.3 CE) en tanto podría entenderse que iniciada la legislatura y habiéndose adquirido el mandato de senador con unas condiciones, se ve modificada la ley con posible restricción de derechos.

34 Ciertamente se trataría de un tema que fácilmente superaría el requisito exigido en el art.50.1.b) de la LOTC sobre la «especial trascendencia constitucional»; así, a la vista de los criterios interpretativos establecidos en la STC 155/2009, se podría contemplar un doble motivo: uno, «Cuando se plantee un problema o una faceta del derecho fundamental o libertad pública sobre el que no haya doctrina del TC»; y dos, «Cuando la vulneración que se denuncia provenga de la ley o de otra disposición de carácter general».

35 Véase una revisión de este principio en la jurisprudencia constitucional en la STC 112/2006. 


\subsection{Otras iniciativas autonómicas similares}

Tras la Ley valenciana, se han presentado otras proposiciones de ley similar en La Rioja $^{36}$ y Castilla y León ${ }^{37}$, a iniciativa del Grupo Parlamentario de Ciudadanos.

En el caso de La Rioja, la Mesa del Parlamento, pese al informe en contra del letrado mayor ${ }^{38}$, acordó admitir a trámite la proposición por tres votos a favor y dos en contra.

En primer lugar hay que recordar que el Parlamento de La Rioja, por su población, sólo designa a un senador y, además, éste debe ser diputado autonómico y simultanear ambos mandatos. La vigente proposición plantea que sea elegido por los diputados autonómicos por mayoría absoluta, en su defecto, en segunda votación será designado el candidato que haya obtenido la mayoría de los votos válidos emitidos y, en caso de empate, resultará designado el candidato propuesto por las fuerzas políticas que hubiesen obtenido mayor número de votos populares en las elecciones. La proposición también incluye, de forma muy similar a la ley valenciana, unas previsiones de comparecencias y rendición de cuentas del senador ante la cámara autonómica.

Respecto a la revocación, esta proposición tiene algunas diferencias respecto a la Ley valenciana. En primer lugar, la iniciativa de la revocación debe contar con el apoyo de un quinto de los miembros del Parlamento y para que prospere requerirá de mayoría absoluta. Así, respecto a la Ley valenciana, se comprueba que la iniciativa requiere el doble de apoyo parlamentario (aunque sin el requisito añadido de que sean dos grupos parlamentarios), pero para su aprobación bastaría con mayoría absoluta, frente a la mayoría reforzada de dos tercios del texto valenciano.

En segundo lugar, la proposición riojana no establece causas de revocación, tan sólo exige que se motive la "pérdida de confianza», por lo que estaríamos ante un evidente supuesto de responsabilidad política similar al que puede existir en los casos de moción de censura al presidente del gobierno en un sistema parlamentario.

La proposición de ley de Castilla y León también preveía que el mandato de los senadores de designación autonómica podría concluir por "pérdida de confianza»,

36 Véase la Proposición de Ley del procedimiento de designación, de las causas de cese y de las relaciones con el Parlamento del senador en representación de la Comunidad Autónoma de La Rioja (Boletín Oficial del Parlamento de La Rioja de 8 de febrero de 2017), que pretende sustituir la anterior Ley $9 / 1994$.

37 Véase la Proposición de Ley admitida por la Mesa el 15 de septiembre de 2017 y publicada en el Boletín Oficial de las Cortes de Castilla y León de 26 de septiembre de 2017.

38 El informe del letrado mayor señalaba que la admisión a trámite de esta ley podría suponer la vulneración del bloque constitucional en el que se incluye el Estatuto de Autonomía en tanto que se estaría modificando el art.19.1.1 sin respetar los requisitos de legitimación de la reforma estatutaria previsto en el art.58 del Estatuto; añade también que la función del Parlamento autonómico se limita a designar al senador autonómico y sería inconstitucional revocar esa designación ya que, una vez adquirida la condición de senador, su régimen y situación de permanencia son los mismos que los del resto de senadores. 
pero debía ser aprobada por unanimidad de todos los diputados autonómicos. También contemplaba la obligatoriedad para el senador designado de las comparecencias anuales o a requerimiento de un tercio de los diputados autonómicos o de dos grupos parlamentarios.

Entre finales de del año 2016 y principios de 2017 hubo otras iniciativas de este tipo en otras Comunidades Autónomas ${ }^{39}$, aunque la aceptación a trámite del recurso de inconstitucionalidad presentado por los senadores populares pudo disuadir y/o paralizar otros intentos hasta comprobar el sentido del pronunciamiento del Alto Tribunal.

\section{APROXIMACIÓN A LA NATURALEZA DEL MANDATO Y LA REVOCACIÓN EN LA DEMOCRACIA REPRESENTATIVA}

\subsection{Aspectos generales}

Los regímenes constitucionales liberales optaron por sistemas de democracia representativa que suponen una nueva concepción del mandato que reciben los miembros de las asambleas representativas, en contraposición al mandato sujeto a instrucciones de los delegados en las asambleas estamentales ${ }^{40}$. El mandato característico de la representación política es un mandato libre, no vinculado, general, nacional y político que se diferencia también así del mandato propio del derecho privado ${ }^{41}$.

El Estado Constitucional es un ente político que, por un lado, tiene dimensiones que imposibilitan la identidad gobernante-gobernado que permitía la polis griega e impide que los ciudadanos puedan pronunciarse de manera permanente acerca de todas las cuestiones públicas, lo que justifica que se atribuya a un número reducido de ciudadanos - los representantes — la competencia para decidir con un cierto grado de independencia sobre los asuntos públicos. Por otro lado, en sus orígenes ${ }^{42}$, algunos también parten de la conveniencia de que se elijan representantes que tengan

39 En la Comunidad Autónoma de Madrid podemos señalar la pregunta del diputado socialista Ángel Gabilondo a la Presidenta del Gobierno, Cristina Cifuentes, por la declaración de intenciones del PP madrileño de proponer el debate y estudio de la reforma de la normativa autonómica para poder revocar a los senadores de designación autonómica, véase el Diario de Sesiones de la Asamblea de Madrid n. ${ }^{\circ} 284$ de 6 de octubre de 2016. Ciertamente, el fallecimiento de la senadora valenciana Rita Barberá unas pocas semanas después parece que pudo influir en sacar de la agenda política esta cuestión.

40 Véase un análisis histórico de la construcción teórica del mandato representativo en TORRES DEL Moral A. (1982). «Crisis del mandato representativo en el Estado de Partidos». Revista de Derecho Político n. ${ }^{\circ}$ 14, pp.7-30.

41 Para un análisis de la evolución de la prohibición del mandato imperativo desde una perspectiva histórica, sociológica y jurídica, ZANON N. (1991). Il libero mandato parlamentare. Saggio critico sull 'articolo 67 della Costituzione. Milano, Giuffré, pp.85 y ss.

42 Véase Torres del Moral, A. (1975). «Democracia y representación en los orígenes del Estado Constitucional». Revista de Estudios Políticos n. ${ }^{\circ}$ 203, pp.145-212. 
la «capacidad necesaria para discutir los asuntos, el pueblo no es en absoluto, apropiado para ello» (Montesquieau) y también como forma de la ideología liberal burguesa de evitar los posibles «excesos» democráticos. Pero, sobre todo, late la idea de que el Parlamento no es un congreso de embajadores de intereses diferentes, y quizá enfrentados, donde cada uno debe mantenerlos a toda costa frente a los demás, es una asamblea deliberativa de una Nación, con un interés de conjunto que debe superar los prejuicios locales o sectoriales (E. Burke, 1774, en su discurso a los electores de Bristol). En este mismo sentido se pronunciará también Condorcet, Torres del Moral explica la evolución de sus posiciones así: «Frente a la doctrina rousseauniana, postula unos diputados que sean verdaderos representantes y no meros comisionados; la elección debe conferir al elegido iniciativa política para cumplir su función. Además, considerando el problema desde su vertiente pragmática, se llega a igual preferencia por una representación más flexible, pues el modelo de mandato imperativo tropieza con la insalvable dificultad de que las instrucciones no pueden prever todas las cuestiones que acaso se susciten en la Cámara ni — menos aún— las soluciones que cabría proponerles». Sin embargo, durante cierto tiempo aún seguirá haciendo referencia a la necesidad de mantener la relación de confianza entre representados y representante, si bien con instrucciones genéricas, con principios generales, sin fijar los detalles, porque «sería peligroso dejar a nuestros diputados una completa libertad ...». No obstante, estos recelos se van extinguiendo tras la experiencia práctica de las Asambleas a partir de 1789 y ya en 1792 sostiene que «Como mandatario del pueblo, haré lo que crea mas conforme a sus intereses. El pueblo me ha enviado para exponer mis ideas, no las suyas; el primero de mis deberes hacia el pueblo es la independencia absoluta de mis opiniones» ${ }^{43}$.

No obstante, también desde los primeros tiempos, se ponen en cuestión estos presupuestos del gobierno representativo y del mandato no vinculado, así, entendiendo que no hay más democracia que la democracia directa, la necesidad fáctica de recurrir a representantes portadores de la voluntad general supone la revocabilidad de estos mandatarios $^{44}$. Así, en los orígenes del Estado liberal, la revocación de los elegidos por parte de sus electores no es incompatible desde un punto de vista teórico y lógico con el principio de representación. Se parte de la idea de que la institución de revocación presupone la existencia de representantes a los que corresponde decidir sobre asuntos públicos que no pueden ser decididos directamente por sus representados, por los ciudadanos. En este contexto, dicha revocación sirve precisamente para exigir responsabilidades a los representantes que se han apartado de las opciones políticas queridas por sus representados, rompiendo el vínculo de confianza que les

43 Para un análisis detallado de la aportación de este autor véase Torres Del MorAL, A. (2004). «Estudio Preliminar», a la traducción comentada del libro de Condorcet (original de 1794) Bosquejo de un cuadro histórico de los progresos del espíritu humano, Madrid, CEPC, pp. LIV y LVI.

44 J.J. Rousseau (1762) en El Contrato Social, Cap. XIII: «El pueblo inglés piensa que es libre y se engaña: sólo lo es durante la elección de los miembros del Parlamento, en cuanto han sido elegidos vuelve a ser esclavo, no es nada». 
unía con estos últimos ${ }^{45}$. De hecho, los argumentos de los liberales detractores del recall no utilizan justificaciones de teoría democrática, si no eminentemente prácticas, así señalan que esa opción contribuye a la inestabilidad gubernamental, que puede ser difícil de articular y apostaban por que la duración del mandato del representante fuese corta y así serían las propias elecciones periódicas la forma de renovar o no la confianza entre electores y elegidos ${ }^{46}$.

Así, la diversidad (social, económica, cultural, etc.) de estos Estados implica diseñar fórmulas para sistemas de gobierno de las mayorías en dialéctica con las minorías y que optarán por la fórmula de la democracia representativa ${ }^{47}$. El sufragio masculino y generalmente censitario presente en los sistemas constitucionales durante el siglo XIX acabará evolucionando hacia el sufragio universal masculino y femenino y, en paralelo, se irá desarrollando un sistema de partidos, y con ellos la disciplina de voto. Así, aunque se mantenga la formalidad de la prohibición del mandato imperativo $^{48}$, los partidos dispondrán de diversos instrumentos para someter a disciplina a los representantes ${ }^{49}$. Sin embargo, para algunos autores, el núcleo esencial del principio jurídico del mandato libre, por ser un elemento consustancial a la democracia representativa, se convierte en un límite implícito a la revisión constitucional ${ }^{50}$.

Este sistema de democracia representativa liberal empieza a dar ciertas señales de «fatiga» ya advertidas por Kelsen ${ }^{51}$ a principios del siglo xx. La inercia de este sistema tiene un elemento tendencial elitista y oligárquico, que va produciendo cierto distanciamiento entre gobernantes y gobernados y que limita la participación del ciudadano a ser elector cada cierto número de años como única forma de exigir responsabilidades a los representantes ${ }^{52}$. Por ello se reivindica la necesidad de for-

45 Ortega Santiago (2005) op. cit. p.148.

46 No es ajeno a esta argumentación el hecho de que autores como Hamilton, Madison o J.S. Mill defendiesen una duración del mandato de los miembros de la Cámara de Representantes de EEUU de tan solo dos años, y se llegó a discutir que fuese sólo de un año, véase OrTEGa (2005) op. cit. pp.150 y ss.

47 Para un análisis amplio de las posiciones doctrinales en torno a la teoría de la democracia representativa, además de las anteriores mencionadas, véase GARCía RoCA, J. (1999). Cargos públicos representativos. Pamplona, Aranzadi, pp.58 y ss. En ZANON (1991) op. cit. pp.323 y ss. se hace un análisis en torno a las posiciones de H. Heller y E. W. Bökenförde sobre el mandato libre de los parlamentarios en la Constitución de Weimar.

${ }^{48}$ Para una visión de derecho comparado, incluidos los antecedentes históricos y teóricos, véase el Informe sobre el mandato imperativo y prácticas similares de la Comisión de Venecia (es el órgano técnico consultivo del Consejo de Europa en materia constitucional) dado en Estrasburgo el 16 de junio de 2009. Véase también otro análisis de derecho comparado sobre las prohibiciones constitucionales del mandato imperativo en VAN DER HUST M. (2000). El mandato parlamentario. Estudio comparativo mundial. Ginebra, Unión Interparlamentaria, pp.8 y ss.

49 Respecto al mandato imperativo impuesto por los partidos políticos, véase la Opinión de la Comisión de Venecia (Sesión Plenaria de los días 10 y 11 de junio de 2016) respecto a la legislación de Ucrania.

50 Zanon (1991) op. cit. p.333.

51 Kelsen, H. (1934). Esencia y valor de democracia, Labor.

52 Otro trabajo pionero en el tema que aquí tratamos es ZampetTi L. (1973). «Democrazia Rappresentativa e Democrazia Partecipativa». Studi in Memoria di Carlo Esposito, Vol. III. Padova: CEDAM. 
talecer el elemento democrático permitiendo que haya mayor participación ciudadana en las actividades políticas, empezando por la necesidad de fortalecer la propia democracia interna de los partidos políticos ${ }^{53}$. También son conocidas las fórmulas clásicas de participación directa dentro de sistemas de democracia representativa como el referéndum y la iniciativa legislativa popular, y en los últimos años se busca intensificar otras formas de participación ciudadana en los procedimientos parlamentarios $^{54}$.

Además de lo anterior, la Ley valenciana 10/2016 ha vuelto a suscitar un viejo debate en torno a la posibilidad de exigir responsabilidad a los gobernantes antes de la finalización del mandato, es decir, la posibilidad de revocación de los cargos electos.

Al no haber en nuestro país normas análogas ${ }^{55}$ sobre revocación por parte de los electores y, también por esa razón, carecer de jurisprudencia que analice posibles casos (a excepción de la reciente STC 123/2017 que luego veremos), nos resulta imprescindible acudir a los pocos supuestos que hemos tenido en los que el TC se ha pronunciado sobre el mandato imperativo al hilo de los problemas suscitados entre los partidos políticos y las personas elegidas bajo sus siglas en diversas citas electorales $^{56}$.

La muy conocida STC 10/1983 resolvía un recurso de amparo planteado por la pérdida de la condición de concejales por haber sido expulsados del partido político bajo cuyas siglas concurrieron a las elecciones, en ella el TC acordaba que el partido político no podía rectificar un mandato representativo de origen popular directo que recaía en las personas elegidas, y concluye que la revocación por parte de su formación política está prohibida para todos los cargos públicos por el derecho fundamental del art.23.2 CE. No obstante, a los efectos de lo que aquí interesa, el Alto Tribunal acepta la tesis de que «La función del representante puede revestir, ciertamente, muy distintas formas y aunque en el entendimiento común y en la opción política de nuestra Constitución (art.1.3) la idea de representación va unida a la de mandato libre, no es teóricamente inimaginable un sistema de democracia mediata o indirecta en la

53 Sobre democracia interna en los partidos políticos, véase NAVARro Méndez J. I. (1999). La democracia interna en los partidos políticos, Madrid, CEC (1999). ZANON (1991) op. cit. p.187 también recuerda como en Alemania, el partido de Los Verdes, reclamando una nueva forma de hacer política y de establecer vínculos estrechos con sus cargos que han obtenido representación, han diseñado un sistema de rotación de los cargos para recuperar el mandato imperativo a favor de las bases del partido.

54 Véase Navarro Méndez, J.I. y Navarro Marchante, V.J. (2016). «La participación ciudadana en los procedimientos parlamentarios de las Comunidades Autónomas: una vía eficaz para combatir la "fatiga del parlamento"». Asamblea, 35, 149-174.

55 Conviene recordar que la posibilidad de revocación popular de los cargos electos municipales (tanto del alcalde como de los concejales) no es extraña en nuestra tradición histórica, se puede citar en este sentido el Estatuto Municipal de 1924 y la Ley Municipal de 1935.

56 Véase, entre otros, Torres del Moral, A. (2011). «Réquiem por el mandato representativo». RDP 81. Pp.11-60. 
que los representantes estén vinculados al mandato imperativo de los representados» (FJ 2..$^{\circ}$ párrafo $4 .^{\circ}$ ). Y añade que «Si todos los poderes del Estado emanan del pueblo, podrá discutirse la conveniencia o, dentro de un sistema representativo concreto, la licitud de la facultad de revocación concedida a los electores, o la oportunidad o la justicia de aquellas normas jurídicas que, de modo general, establezcan como consecuencia necesaria de ciertos supuestos de hecho, el cese del representante en las funciones que el pueblo le ha conferido. No es, por el contrario, constitucionalmente legítimo otorgar a una instancia que no reúne todas las notas necesarias para ser considerada como un poder público, la facultad de determinar por si misma ese cese sujetándose sólo a las normas que libremente haya dictado para sí».

Por tanto, el TC acepta que la posibilidad de revocación de los representantes por parte de los representados no plantea contradicción teórica con los postulados de la democracia representativa. La idea de democracia y el principio del origen popular del poder no se ven menoscabados porque el sistema de representación contemple la posibilidad de revocación, que no es otra cosa que permitir que los electores puedan rectificar su elección y poner fin a la presunción de la representación antes de la finalización de la legislatura. Ahora bien, la propia STC 10/1983 recuerda que en nuestra Constitución hay una norma específica que impide que se sujete a «los representantes al mandato de los representados de la forma que, con referencia a los miembros de las Cortes Generales prohíbe expresamente el art.67.2 de nuestra Constitución» (FJ 2. ${ }^{\circ}$, párrafo cuarto $)^{57}$.

Recientemente (STC 151/2017, de 21 de diciembre), el TC ha tenido que pronunciarse sobre la constitucionalidad de la última reforma del art.197.1.a) de la LOREG que, con la intención de combatir el transfuguismo y asegurar la voluntad popular y la estabilidad municipal, exigía un quórum reforzado cuando entre los firmantes de la propuesta de moción de censura contra el alcalde haya concejales que «por cualquier causa» hayan dejado de pertenecer al grupo político del alcalde y no estén adscritos a ningún partido. El pleno del Alto Tribunal ${ }^{58}$ ha entendido que el precepto recurrido vulnera el art.23.2 CE en tanto que las funciones esenciales del derecho de participación política «se atribuyen a su titular y en condiciones de igualdad, y no al partido o grupo en el que se integre». Además, señala que el mandato libre supone «la exclusión de todo sometimiento jurídico del represen-

57 ZANON (1991) op. cit. p.292, analizando el actual ordenamiento jurídico italiano, también llega a la conclusión de la admisibilidad política o de facto del mandato imperativo del «parlamentario — con sus electores, con su partido o con otros sujetos_- (...) pero ninguna de tales relaciones puede disponer de garantía jurídica alguna». La disciplina de voto del parlamentario respecto a su propio partido es un tema también ampliamente tratado por la doctrina española, véase por todos, por reciente, Holgado González (2017): «El estatuto jurídico-político del diputado: entre la lealtad al partido y la lealtad a su electorado». REDC 11, pp.45-65.

58 La STC cuenta con tres votos discrepantes (Conde-Pumpido, Xiol y Montoya) que entienden que la norma es equilibrada en tanto que de ella se derivan «más beneficios o ventajas para el interés general que perjuicios sobre otros bienes o intereses en conflicto, incluido el ius in officium de los concejales». 
tante, en cuanto tal, a voluntades ajenas»y proscribe «cualquier tipo de sujeción, jurídicamente impuesta, a la confianza de sus electores o de las organizaciones o grupos políticos en que se integre o en cuyas listas hubiera concurrido a las elecciones» (FJ 6. . .c) pf.2..$^{\circ}$.

Como venimos señalando, el ordenamiento jurídico español no contempla la posibilidad de revocación de ningún representante elegido para formar parte de un órgano de naturaleza asamblearia ${ }^{59}$, aunque algún autor ha defendido la viabilidad de su implantación en el ámbito local ${ }^{60}$. Entendemos que no resulta equiparable establecer una analogía con la posibilidad de censurar a las personas que ocupan cargos ejecutivos, como es el caso, por ejemplo en nuestros sistemas de gobierno parlamentario, de la moción de censura a los presidentes de gobierno por parte del correspondiente órgano legislativo que le dio la investidura o de un alcalde por parte de los concejales $^{61}$. También es destacable, aunque tampoco es posible establecer una analogía, como un caso único en el derecho parlamentario español, la previsión del Reglamento del Parlamento de Navarra (art.39.3c) que permite que el Presidente de la Cámara y los restantes miembros de la Mesa sean cesados por «remoción del cargo acordado por el Pleno de la Cámara por mayoría de tres quintos».

También existe una elección de segundo grado para formar parte de un órgano de naturaleza asamblearia ${ }^{62}$ en el caso de los miembros de las Diputaciones Provinciales, regulado en el RD 2568/1986 que aprueba el Reglamento de Organización y Funcionamiento y Régimen Jurídico de las Entidades Locales; su art.9 regula las causas de pérdida de la condición de concejal, miembro de la diputación provincial o de cualquier entidad local, y se trata de causas objetivas, y tampoco se prevé la revocación por parte de los concejales de los miembros de la Diputación Provincial.

Para García Roca ${ }^{63}$ tan cargo representativo es el que procede del sufragio directo como del indirecto y la existencia de una representación política de los

59 El único caso de revocación de un representante en un órgano asambleario (o cuasi asambleario) que se contempla en nuestro derecho (hasta donde sabemos) es el previsto para la elección de los representantes de los trabajadores en las empresas (art. 67.3 del Estatuto de los Trabajadores, y en paralelo en las Leyes de la función pública).

60 Véase Dueñas Castrillo, A.I. (2017): «La incidencia de los partidos políticos en el revocatorio del mandato en los ayuntamientos españoles». Partidos políticos y mediaciones de la democracia directa, Coord. Paloma Biglino Campos. Madrid, CEPC, pp.117-150, que sostiene que es posible introducir el referéndum revocatorio del mandato (tanto del alcalde como de los concejales) en el ámbito de los Ayuntamientos españoles mediante reforma de la LOREG.

${ }^{61}$ Véase el art. 113 de la CE y los equivalentes en los diecisiete EEAA. En el caso de la moción de censura a los alcaldes véase art.22.3 y 33.3 LBRL de 1985. El art.197.4 de la LOREG (tras la reforma de la LO 8/1999) posibilita la destitución del Alcalde de municipios de Concejo Abierto mediante moción de censura constructiva, para presentarla y que prospere se requiere mayoría absoluta de los electores.

${ }^{62}$ También hubo una designación indirecta de los primeros europarlamentarios españoles, al ingresar España en la CEE en 1986, cuando el Congreso de los Diputados los designó con un régimen transitorio hasta las primeras elecciones europeas en 1987.

63 Op. cit. p.49. 
ciudadanos o, lo que es lo mismo en un Estado democrático, de algún grado de conexión con el sufragio activo, mediante la existencia en el origen de una concurrencia electoral por sufragio universal, «es el criterio jurídico que permite identificar — más allá de toda duda razonable — el ámbito objetivo del derecho fundamental» del art.23 CE.

De hecho, dado nuestro vigente sistema electoral para las elecciones generales, con circunscripciones básicamente plurinominales con sistema proporcional, resultaría imposible articular un sistema de revocación por los electores de sólo uno de los representantes elegidos que fuese admisible.

En los sistemas de gobierno presidencialistas, con Jefes de Estado de elección popular directa, pueden encontrarse ejemplos en los que se prevé la posibilidad de celebrar un referéndum revocatorio o recall ${ }^{64}$. También pueden observarse normas similares en algunos Estados de México (Chihuahua o Yucatán), de Argentina (Ciudad Autónoma de Buenos Aires o La Rioja), de Suiza o EE.UU. Habitualmente la iniciativa de la celebración del referéndum debe partir de los propios ciudadanos, que deberán reunir un determinado número de firmas de electores para provocar la celebración del referéndum revocatorio, que para tener resultado vinculante puede requerir un determinado porcentaje de participación.

Parece evidente que la revocación guarda íntima relación con la problemática del mandato imperativo. En la medida en que se considere que el parlamentario está jurídicamente vinculado por las promesas efectuadas a sus electores, no es en efecto ilógico permitir a sus electores que le revoquen si no cumple sus promesas. Ese era el caso de los antiguos países del Este y lo es todavía en algunos países que siguen aplicando el mandato imperativo (Cabo Verde, Cuba, Fiji, Indonesia, ...). No obstante, también se prevé la revocación de los representantes parlamentarios en otros Estados que tienen fórmulas de mandato representativo como Etiopía, Filipinas, Gabón, Laos o Zambia ${ }^{65}$.

\subsection{Aspectos específicos en torno a los senadores de designación autonómica}

Sin embargo, la Ley valenciana 10/2016 planteaba un asunto diferente, no se trataba de atender a la pérdida del cargo por decisión del partido político bajo cuyas siglas se presentó la persona que resultó luego elegida por los ciudadanos, algo que ya ha quedado superado desde los primeros pronunciamientos del TC, y tampoco se trataba de analizar la eventual revocación del representante elegido de forma directa por parte de los ciudadanos electores. Se centraba la cuestión en la posible revocación de los senadores de designación autonómica por parte de la Cámara designante, en un caso de elección de representantes de segundo grado.

${ }^{64}$ La vigente Constitución de Venezuela contempla esta posibilidad tanto para el Presidente de la República (art.72) como para los diputados de la Asamblea Nacional (art.197).

65 VAN DER Hust (2000) op. cit., p.19. 
La doctrina mayoritaria ${ }^{66}$ venía entendiendo que la naturaleza de la relación que se establece entre la asamblea designante y el senador designado puede calificarse como de cooperación. En consecuencia, es también mayoritaria ${ }^{67}$ la tesis de la irrevocabilidad del mandato de los senadores designados, aunque algunos como Asensi Sabater y Sevilla Merino ${ }^{68}$, han defendido la posibilidad de revocación, argumentando que el constituyente emplea para éstos el término «designación» por parte de las asambleas legislativas autonómicas y no «elección» como hace para los demás casos y también que en nuestro sistema jurídico hay revocabilidad en las elecciones de segundo grado ${ }^{69}$. Aunque incluso estos mismos autores, también sus críticos ${ }^{70}$, admiten que dado el sistema actual de designación en los parlamentos autonómicos con garantía de proporcionalidad, la revocación sería muy difícil de articular en la práctica.

66 Así Barrero Valverde J.I. (1998). «Las relaciones entre el Senado y las Asambleas Legislativas de las Comunidades Autónomas». Corts, 6, p.68: «las solicitudes de los Parlamentos autonómicos para que comparezcan e informen los senadores por ellos designados, sin llegar nunca al control del Senador designado, ya que el mandato representativo supone la carencia de relación de responsabilidad entre ambas partes». Para Punset (1983) op.cit. p.170: «Dada la prohibición de mandato imperativo que afecta a todos los miembros del Senado (art.67.2) y habida cuenta del carácter estatal de dicha Cámara, parece claro que en términos jurídicos, la relación en cuestión es unidireccional y se agota en el acto de designación». En el mismo sentido se pronuncia Cuenca Miranda A. (2003). «Los senadores designados por las Comunidades Autónomas». Asamblea (especial monográfico La Asamblea de Madrid: dos décadas de Parlamento Autonómico), pp.155 y ss. que entiende que el art.67 garantiza que el senador designado es «enteramente libre a la hora de emitir su voto y, en general, de ejercer sus funciones parlamentarias (...) aunque no han faltado supuestos conflictivos». Este último también recuerda (2003, p.155) el caso de una Resolución aprobada por el Pleno de las Cortes Valencianas sobre «actuación de los senadores valencianos en defensa de las competencias de la Generalitat en materia de Régimen Local», de 21 de noviembre de 1984, por la que se instaba a los Senadores Valencianos (a todos) a actuar en una determinada dirección en la tramitación del Proyecto de Ley de Bases de Régimen Local, y que en su momento contó con cierto apoyo doctrinal.

${ }^{67}$ Punset (1983) op.cit. p.182: «Puesto que «Las Cortes Generales representan al pueblo español» (art.66.1 de la Constitución), los miembros de las Cortes Generales no estarán ligados por mandato imperativo (art.67.2); o sea, Diputados y Senadores ejercen una función jurídicamente independiente: no pueden recibir instrucciones de sus electores (o designantes) ni ser objeto de revocación anticipada por ellos. La prohibición de mandato imperativo afecta también, desde luego, a los senadores comunitarios»; CAAmaño Domínguez F. (1991). El mandato parlamentario. Madrid, Congreso de los Diputados. p189; García-Escudero (1995) op.cit. p.140: «dada la prohibición de mandato imperativo que afecta a todos los miembros de las Cortes Generales, puede decirse que la relación es unidireccional y se agota en el acto de designación, con lo cual la autonomía-participación conferida a las Comunidades Autónomas se concreta en la facultad de designar»; Ortega Santiago (2005) op.cit.p.54: «no corresponde a las Asambleas legislativas autonómicas la facultad de revocar a los Senadores que designa, facultad que sí supondría propiamente una limitación inconstitucional del mandato representativo de dichos Senadores».

68 Asensi Sabater J. y Sevilla Merino, J. (1986). «La designación de senadores comunitarios en la perspectiva de la territorialización del Senado». Jornadas de Parlamentos Autónomos. Corts Valencianes, p.107.

69 Estos han sido justamente dos de los argumentos empleados por los defensores de la Ley valenciana 10/2016 para sostener su constitucionalidad.

70 García Escudero P. (2006). «A vueltas con la reforma constitucional del Senado: de las opciones a las decisiones». TRC, 17, p.209. 
A nuestro juicio, el empleo del término «designación» para estos senadores responde a que, en definitiva, se trata ciertamente de una elección de segundo grado, que no es realizada directamente por elección de los ciudadanos. Respecto al segundo de los argumentos, la existencia en nuestro sistema jurídico de diversos ejemplos de revocación de determinados cargos con legitimidad democrática indirecta (téngase presente, por ejemplo, la forma de elección del Presidente del Gobierno de España, art.99 CE, y sus numerosos paralelismos de elecciones realizadas por órganos de naturaleza asamblearia), creemos que no son equiparables en tanto se trata de mociones de censura a cargos ejecutivos, no a cargos representativos que se integran en un órgano de naturaleza asamblearia como es el caso de los senadores de designación autonómica.

Creemos que la eficacia de la prohibición constitucional del mandato imperativo opera como garantía del representante no sólo frente a sus electores, sino también frente a cualesquiera ataques de poderes públicos y/o privados (órganos rectores de las Asambleas, partidos políticos, Grupos Parlamentarios u otros). Coincidimos con García Roca ${ }^{71}$ en que «nada autoriza a restringir donde el art.67.2 CE no lo hace» y añade que la conjunción de los arts.23.2 y 67.2 supone, en definitiva, la garantía constitucional de una privilegiada posición constitucional del cargo público representativo que se hace en atención a su legitimidad democrática de primer o segundo grado. Además, es necesario poner de manifiesto que la rigurosa interdicción del mandato imperativo en nuestro ordenamiento, además de ser una prohibición constitucional expresa ${ }^{72}$, es una «consecuencia lógica e inevitable de la consagración del principio de representación nacional que se recoge en el art.1.2 y 66.1 CE, pues es unánime en la doctrina más solvente la consideración de que no puede hablarse de representación nacional si al tiempo rige el mandato imperativo» ${ }^{73}$.

\section{LA STC 123/2017, DE 2 DE NOVIEMBRE}

El pleno del TC, por unanimidad, y teniendo como ponente al Magistrado Xiol Rios, acordó la declaración de inconstitucionalidad de todos los apartados recurridos

71 García Roca (1999) op.cit. p.123.

72 La Constitución Italiana de 1948, también en su art.67, recogía el mismo principio de prohibición de la limitación del mandato libre del parlamentario, según Zanon (ZANON, N. (2001). «La rappresentanza della nazione e il libero mandato parlamentare». Il Parlamento. Torino, Einaudi, p.683) porque el principio de representación nacional hace que el parlamentario no sea representante de un determinado colegio o circunscripción electoral, sino de toda la Nación, sometido por tanto a los intereses generales y no a intereses locales o particulares, de sus propios partidos o de grupos de presión. Por ello, entiende que el art.67 de la Constitución Italiana implica «la inconstitucionalidad de una ley que prevea la posibilidad de revocar del cargo a un parlamentario, o de una norma del Reglamento parlamentario que prevea la pérdida del cargo para el parlamentario que abandona el grupo parlamentario del partido por el que fue elegido para vincularse a otro».

73 García Roca (1999) op. cit.125. 
de la Ley valenciana 10/2016 (apartados uno, tres, cuatro, cinco y siete del artículo único), tanto los referidos a la posibilidad de revocación del senador de designación autonómica como los referidos a la obligatoriedad de las comparecencias del senador ante la cámara designante.

Respecto a la posibilidad de revocación del senador por la cámara legislativa autonómica designante, la STC $123 / 2017^{74}$ recuerda cuál debe ser el estatus jurídico a considerar (F.J.3. ${ }^{\circ}$, apartado B) por el que «Una vez designados e integrados en la Cámara de representación territorial (art.69.1 CE), los senadores de origen autonómico ostentan posición constitucional idéntica a la de los demás miembros de las Cortes Generales y les es de aplicación, en particular, el régimen jurídico común que la Constitución dispone para cualesquiera senadores», con las únicas peculiaridades de las posibles pérdidas de las condiciones objetivas de elegibilidad o incompatibilidad fijadas en los respectivos EE.AA. o leyes a las que se remitan o por diferente criterio de cómputo de la duración del mandato. Por tanto, estos senadores, al igual que los restantes senadores y diputados, representan al conjunto del pueblo español como una «unidad ideal de imputación» y a todos ellos por igual es aplicable el principio del mandato libre en virtud del artículo 67.2 CE que supone «la exclusión de todo sometimiento jurídico del representante, en cuanto tal, a voluntades políticas ajenas y proscribe por ello, en particular, que sobre él se hicieran pesar tanto instrucciones vinculantes en Derecho» procedentes de «sus electores (expresada del modo que se pretendiera) o de las organizaciones o grupos políticos en que se integre o en cuyas listas hubiera concurrido a las elecciones; sujeción que, de llegar a verificarse, contrariaría asimismo, adicionalmente, sus derechos al mantenimiento en el cargo y a ejercerlo sin constricciones ilegítimas (art.23.2 CE)».

Además de lo anterior, que ya supone descartar la constitucionalidad de cualquier norma infraconstitucional que prevea una revocación de cualquier miembro de las Cortes Generales, la STC (F.J.6. ${ }^{\circ}$ B) reprocha en particular que sea el legislador autonómico el que pretenda asumir competencia alguna para imponer «deberes o controles sobre miembros de órganos constitucionales del Estado» más allá de lo relacionado con la designación.

La otra cuestión principal que resuelve el Alto Tribunal es lo referido al establecimiento de la obligatoriedad de las comparecencias del senador autonómico ante la cámara designante. La STC trata en fundamentos jurídicos diferenciados la doble inclusión de comparecencias de carácter obligatorio previstas en la ley valenciana, así dedica el F.J.4. ${ }^{\circ}$ a la comparecencia solicitada a instancia de los grupos parlamentarios autonómicos y en el F.J.5..$^{\circ}$ se trata la introducción de la compare-

${ }^{74}$ La STC 123/2017 resuelve únicamente el recurso planteado por el grupo de senadores populares. El recurso del Presidente del Gobierno, que se tramitó con más retraso (por los plazos del intento de conciliación del art.33.2 de la LOTC), fue resuelto con la posterior STC 141/2017, de 30 de noviembre, cuyo fallo declara la pérdida de objeto de ese segundo recurso sobre la norma valenciana en tanto ya había sido resuelto con la STC 123/2017. 
cencia anual regular ante la Comisión de Coordinación, Organización y Régimen Jurídico de las Instituciones de la CAVal para rendir cuentas de su trabajo en el Senado.

El F.J.4. ${ }^{\circ} \mathrm{A}$ de la STC argumenta que las previsiones de las normas autonómicas sobre comparecencias informativas del senador son «inocuas desde el punto de vista de la constitucionalidad, en tanto se limiten a contemplar meras iniciativas parlamentarias con efectos jurídicos acotados a la vida interna de las Cámaras y sin alcance vinculante alguno, por lo tanto, para el senador cuya presencia se interesa». Sin embargo, tales normas autonómicas no pueden «imponer deber de tipo alguno sobre aquellos senadores, miembros de un órgano constitucional del Estado por entero sustraído a las competencias de las Comunidades Autónomas». En este punto, evita el Tribunal de forma expresa entrar a valorar la validez de una norma de este tipo que estuviese prevista en la norma estatutaria, con rango de ley orgánica, del Estado, como ocurre con el art.50.1 del Estatuto balear de 2007, y que es esgrimida como argumento de la parte defensora de la constitucionalidad de la ley valenciana $^{75}$.

Sin embargo, el TC, en el F.J.5..$^{\circ}$, al valorar la constitucionalidad de las comparecencias regulares anuales ante la pertinente Comisión del parlamento autonómico, es más contundente al señalar que se trata de un precepto inconstitucional «tanto en atención a consideraciones competenciales como sustantivas». Es decir, a la falta de competencia del legislador autonómico para establecer esas comparecencias ya señaladas en el fundamento jurídico anterior, ahora añade una razón sustantiva pues tal obligación implicaría admitir que el senador de designación autonómica se encuentra «en una inequívoca situación de subordinación a la asamblea, o de dependencia política de la misma, al modo de relación fiduciaria que vincula a un gobierno parlamentario (...) y contraviene explícitamente, de este modo, lo prescrito en el art.67.2CE». Añade el TC que tal previsión «solo podría haber sido establecida por la Constitución misma, no por ninguna otra fuente, estatal o autonómica, a ella subordinada».

A nuestro juicio, no nos parece justificado que la argumentación de la inconstitucionalidad de las comparecencias obligatorias a instancia de los grupos parlamentarios se fundamente sólo en razones de falta de competencia del legislador autonómico, sin mención de la posible vulneración del art.67.2 CE, y que sí se utilice este argumento para el caso de las comparecencias regulares anuales. Entendemos que, en ambos casos, se estaría partiendo de una eventual relación de dependencia de idéntica naturaleza, aunque tuviesen fórmulas de concreción diferentes (petición de los grupos parlamentarios en un caso y previsión temporal regular anual en otro) y en ambos casos con sustento en norma legal autonómica.

75 Señala la STC F.J.4. ${ }^{\circ}$, in fine: «El Tribunal, en todo caso, no ha de pronunciarse ahora sobre si la norma que así hemos de declarar inconstitucional no lo hubiera sido de haber estado contenida en el $\mathrm{EACV}$. 


\section{CONCLUSIONES}

Primera: Tal y como era previsible ${ }^{76}$, el TC, por unanimidad y en un breve plazo de tiempo, acordó la inconstitucionalidad de los preceptos recurridos de la norma autonómica valenciana. En primer lugar, en lo referido a la posibilidad de revocación del senador de designación autonómica por parte de la cámara designante, por vulneración del art. 67.2 CE sobre la prohibición del mandato imperativo, en conexión con el art.23.2 y 1.2 CE. En segundo lugar, por establecer, con carácter obligatorio, las comparecencias del senador de designación autonómica ante la cámara autonómica designante, tanto a petición de los grupos parlamentarios autonómicos como las de periodicidad regular anual, por falta de competencia del legislador autonómico y por vulnerar también el principio del mandato libre del art.67.2 CE.

Segunda: También aprecia la STC falta de competencia del legislador autonómico para ocuparse del régimen jurídico de los miembros de un órgano estatal, por tanto también una vulneración del principio de la autonomía parlamentaria del art.72.1 CE.

Tercera: No obstante, por otra parte, si se quiere buscar una segunda cámara legislativa que no sea una duplicidad inútil del Congreso y que cumpla realmente su función de cámara territorial ${ }^{77}$, no parece absurdo pensar que sería conveniente articular fórmulas para que los senadores de designación autonómica (que quizá debieran ser los únicos), mantuviesen relación y vínculo permanente con las respetivas CCAA designantes ${ }^{78}$. Ciertamente, por tanto, para introducir la posibilidad de revocación de los senadores de designación autonómica se requiere una específica previsión consti-

76 Así lo habíamos anunciado en la comunicación presentada en el Congreso de la ACE celebrado en marzo de 2017 en León, puede verse aquel texto en https:/congresoace.files.wordpress.com/2017/03/ mesa1comunicacionvnavarro.pdf

77 Ciertamente, la doctrina no es unánime sobre la viabilidad de la articulación del Senado como auténtica cámara de representación territorial. Entre los argumentos de los defensores estarían: a) la designación de senadores autonómicos permitiría objetivar en el Senado la voluntad e interés de las CC.AA. y no como trasunto de los partidos políticos; b) hay un déficit de participación de las CC.AA en la formación de la voluntad general, achacable a la falta de funcionalidad del Senado; c) el Senado es una institución esencial en los Estados compuestos porque garantizan la pluralidad de las partes frente a la unidad del todo. Sin embargo, Garrido López C. (2016). «Pero, ¿puede ser el Senado una cámara de representación territorial?» REDC, 107, p.92 y ss., tras un análisis de derecho comparado, sostiene que el Senado de los sistemas federales, independientemente de la forma de elección de los senadores y de sus funciones, no escapa de la dinámica partidista que neutraliza la supuesta voz propia de los estados miembros.

78 Pizzorusso A. (1980). «Democrazia pertecipativa e attività parlamentari». AA.VV. Parlamento, Istituzioni e Democrazia, Actas del Seminario de Roma, 11-13 de diciembre de 1979, Milano, pp136 y ss. cree que una eventual transformación del Senado italiano en una Cámara de las Regiones implicaría una derogación parcial de la previsión del art.67 de la Constitución Italiana de prohibición del mandato imperativo. También en nuestro país sería necesario eliminar la exigencia constitucional de mandato libre para los senadores. 
tucional que actualmente no existe ${ }^{79}$, por lo que sería necesario, y también recomendable, una reforma constitucional de calado sobre nuestro sistema bicameral.

\section{BIBLIOGRAFÍA}

Agulló, R. (2004): «La designación de senadores por las Comunidades Autónomas ante la reforma del Senado», documento de trabajo disponible en la base de datos de Banco de Conocimientos del INAP https://bci.inap.es

Asensi Sabater, J. y Sevilla Merino, J. (1986). «La designación de senadores comunitarios en la perspectiva de la territorialización del Senado». Jornadas de Parlamentos Autónomos. Corts Valencianes, 107-127.

Barrero Valverde, J.I. (1998). «Las relaciones entre el Senado y las Asambleas Legislativas de las Comunidades Autónomas». Corts, 6, 65-77.

CaAmaño Domínguez, F. (1991). El mandato parlamentario. Madrid, Congreso de los Diputados.

Cuenca Miranda, A. (2003). «Los senadores designados por las Comunidades Autónomas». Asamblea (especial monográfico La Asamblea de Madrid: dos décadas de Parlamento Autonómico), 143-167.

Dueñas Castrillo, A.I. (2017): «La incidencia de los partidos políticos en el revocatorio del mandato en los ayuntamientos españoles». Partidos políticos y mediaciones de la democracia directa, Coord. Paloma Biglino Campos. Madrid, CEPC, pp.117-150.

García-Escudero Márquez, P. (1995). Los senadores designados por las Comunidades Autónomas. Madrid, Cortes Generales y CEC.

García-Escudero MÁrquez, P. (2006). «A vueltas con la reforma constitucional del Senado: de las opciones a las decisiones». TRC, 17, 195-221.

García Roca, J. (1999). Cargos públicos representativos. Pamplona, Aranzadi.

GARrido López, C. (2016). «Pero, ¿puede ser el Senado una cámara de representación territorial?»REDC, 107, 75-116.

Holgado GonZÁlez, M. (2017): «El estatuto jurídico-político del diputado: entre la lealtad al partido y la lealtad a su electorado». REDC, 111, pp.45-65.

Kelsen, H. (1934). Esencia y valor de democracia, Labor.

Meyer, H. (2006). «Los votos en el Bundesrat». TRC, 17, 65-105.

Navarro MéndeZ, J. I. (1999). La democracia interna en los partidos políticos, Madrid, CEC.

79 La doctrina norteamericana, ante la ausencia de un pronunciamiento específico del Tribunal Supremo, entiende que la posibilidad de la revocación de miembros del Congreso y del Senado, bien fuesen elegidos por los legislativos de los Estados o bien directamente por voto popular, que se incluyese en las normas estatales exigiría que así se reconociese expresamente en la Constitución Federal en tanto que el acceso y permanencia en el cargo es una materia que corresponde a la Federación, Ortega Santos (2005) op.cit.p.153. 
Navarro Méndez, J. I. y Navarro Marchante, V. J. (2016). «La participación ciudadana en los procedimientos parlamentarios de las Comunidades Autónomas: una vía eficaz para combatir la "fatiga del parlamento"». Asamblea, 35, 149-174.

Núñez Martínez, M. y Reviriego Picón, F. (2006). «Repertorio bibliográfico sobre el Senado». TRC, 17, 449-474.

Ortega Santiago, C. (2005). El mandato representativo de los diputados y senadores. Madrid, Congreso de los Diputados.

Pauner Chulvi, C. (1997). «Los requisitos de elegibilidad de los senadores de designación autonómica». Revista de las Cortes Generales, 41, 123-151.

Pizzorusso, A. (1980). «Democrazia pertecipativa e attività parlamentari. AA.VV. Parlamento, Istituzioni e Democrazia», Actas del Seminario de Roma, 11-13 de diciembre de 1979, Milano.

Punset, R. (1983). «La designación de senadores por las Comunidades Autónomas». REDC, $8,161-185$.

Sessano Goenaga, J. C. (2003). «El delito de incomparecencia ante comisiones parlamentarias de investigación como delito de «infracción de deber»; el sujeto activo de la conducta delictiva: el autor típico como obligado especial con un rol institucional». Anales de Derecho, 21. Universidad de Murcia, 283-298.

Torres del Moral, A. (1975). «Democracia y representación en los orígenes del Estado Constitucional». Revista de Estudios Políticos, 203, pp.145-212.

Torres del Moral, A. (1982). «Crisis del mandato representativo en el Estado de partidos». RDP, 14, pp.7-30.

Torres del Moral, A. (2003-2004). «Veinticinco años de Senado». RDP,58-59, pp.481-499.

Torres del Moral, A. (2004). «Estudio Preliminar» a la obra de Condorcet (original de 1794), Bosquejo de un cuadro bistórico de los progresos del espíritu bumano, Madrid, CEPC.

Torres Del Moral, A. (2011). «Réquiem por el mandato representativo». RDP, 81, pp.11-60.

Trujillo Fernández, G. (1978). «La regionalización del Estado». Estudios sobre el proyecto de la Constitución. Madrid, CEC, pp.501 y ss.

VAN DER Hust, M. (2000). El mandato parlamentario. Estudio comparativo mundial. Ginebra, Unión Interparlamentaria.

Visiedo Mazón, F. J. (2002). «La designación de senadores en la Comunidad Valenciana, artículo 11.j) del Estatuto de Autonomía: las limitadas posibilidades de mejora a través de la reforma de la ley de designación y del reglamento de las Cortes Valencianas». Corts, 12, 269-304.

VV.AA. (1996). El Senado, Cámara de representación territorial. III Jornadas de la AELPA. Madrid, Tecnos.

VV.AA. (1999). «Bibliografía sobre el Senado español y otras cámaras altas de representación territorial». Revista de las Cortes Generales, 47, 305-380. 
ZampetTi, L. (1973). «Democrazia Rappresentativa e Democrazia Partecipativa». Studi in Memoria di Carlo Esposito, Vol. III. Padova: CEDAM.

Zanon, N. (1991). Il libero mandato parlamentare. Saggio critico sull 'articolo 67 della Costituzione. Milano, Giuffré.

ZANON, N. (2001). «La rappresentanza della nazione e il libero mandato parlamentare». Il Parlamento. Torino: Einaudi, 683-695.

Title:

The Revocation of Senators of autonomic designation (Valencian Law 10/2016 and STC 123/2017)

\title{
Resumen:
}

La Comunidad Autónoma Valenciana aprobó a finales del pasado año la Ley 10/2016 que modificaba varios aspectos de la ley territorial que regulaba diferentes aspectos en torno a la designación de senadores en representación de la Comunidad Autónoma. La nueva norma introduce, de forma novedosa en nuestro derecho, la posibilidad de revocación del senador designado por el parlamento autonómico, además de establecer la obligatoriedad del senador de comparecencia ante la cámara designante como forma de rendición de cuentas. La posibilidad de revocación del senador por pérdida de confianza de la cámara autonómica planteaba dudas de constitucionalidad por, entre otros, posible vulneración de la prohibición de mandato imperativo de los miembros de las Cortes Generales, ya resueltas por la STC 123/2017. El presente artículo, al hilo del análisis de la norma valenciana y su encaje constitucional, reflexiona sobre la naturaleza del mandato representativo y la peculiar función de la cámara de representación territorial.

\begin{abstract}
:
The Valencian Autonomous Community approved at the end of last year the Law 10/2016 that modified several aspects of the territorial law that regulated different aspects about the appointment of senators in representation of the Autonomous Community. The new norm introduces, in a novel way in our right, the possibility of revocation of the senator appointed by the autonomic parliament, in addition to establishing the mandatory of the senator of appearance in the designating chamber as a form of accountability. The possibility of revocation of the senator due to loss of confidence of the autonomous chamber raises doubts of
\end{abstract}


constitutionality by, among others, possible violation of the prohibition of imperative mandate of the members of the Cortes Generales, already resolved by STC 123/2017. This article, along the lines of the analysis of the Valencian norm and its constitutional reserve, reflects over the nature of the representative mandate and the peculiar function of the chamber of territorial representation.

\section{Palabras clave:}

Revocación, senadores autonómicos, mandato representativo, mandato imperativo.

Key words:

Revocation, territorial senator, representative mandate, imperative mandate. 